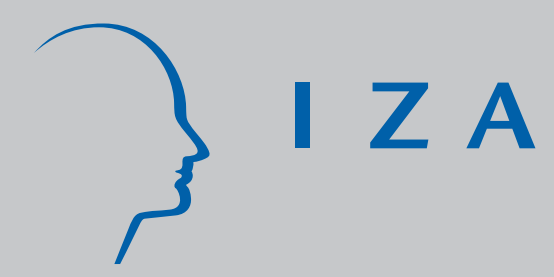

IZA DP No. 868

Analyzing Religiosity Within an Economic Framework: The Case of Spanish Catholics

Pablo Brañas Garza

Shoshana Neuman

August 2003 


\title{
Analyzing Religiosity Within an Economic Framework: The Case of Spanish Catholics
}

\author{
Pablo Brañas Garza \\ University of Jaén \\ Shoshana Neuman \\ Bar-llan University, CEPR \\ and IZA Bonn
}

\section{Discussion Paper No. 868 \\ August 2003}

\author{
IZA \\ P.O. Box 7240 \\ D-53072 Bonn \\ Germany \\ Tel.: +49-228-3894-0 \\ Fax: +49-228-3894-210 \\ Email: iza@iza.org
}

\begin{abstract}
This Discussion Paper is issued within the framework of IZA's research area The Future of Labor. Any opinions expressed here are those of the author(s) and not those of the institute. Research disseminated by IZA may include views on policy, but the institute itself takes no institutional policy positions.
\end{abstract}

The Institute for the Study of Labor (IZA) in Bonn is a local and virtual international research center and a place of communication between science, politics and business. IZA is an independent, nonprofit limited liability company (Gesellschaft mit beschränkter Haftung) supported by Deutsche Post World Net. The center is associated with the University of Bonn and offers a stimulating research environment through its research networks, research support, and visitors and doctoral programs. IZA engages in (i) original and internationally competitive research in all fields of labor economics, (ii) development of policy concepts, and (iii) dissemination of research results and concepts to the interested public. The current research program deals with (1) mobility and flexibility of labor, (2) internationalization of labor markets, (3) welfare state and labor market, (4) labor markets in transition countries, (5) the future of labor, (6) evaluation of labor market policies and projects and (7) general labor economics.

IZA Discussion Papers often represent preliminary work and are circulated to encourage discussion. Citation of such a paper should account for its provisional character. A revised version may be available on the IZA website (www.iza.org) or directly from the author. 
IZA Discussion Paper No. 868

August 2003

\section{ABSTRACT}

\section{Analyzing Religiosity Within an Economic Framework: The Case of Spanish Catholics}

Using a sample of Spanish Catholics, we examined the level of religiosity (measured by beliefs, prayer and church attendance) and the relationship between religiosity and various socio-economic variables. An Ordered Logit estimation of religiosity equations showed that: women are more religious than men; religious activity increases with age; there is a (marginally) significant positive relationship between schooling and religiosity; religiosity is positively related to exposure to religious activity during childhood; and male religious activity is positively affected by marital status (being married to a catholic wife) and by the number of children at home. The results also demonstrate the importance of the "salvation motive" for the two genders and the presence of the "professional utilitarian motive" in male religious behaviour.

JEL Classification: Z12, I21

Keywords: $\quad$ religiosity, prayer, church attendance, education, Spain, Ordered Logit

Corresponding author:

Shoshana Neuman

Department of Economics

Bar-llan University

52900 Ramat-Gan

Israel

Tel.: +972 35318393

Fax: +972 35353180

Email: neumans@mail.biu.ac.il 


\section{Introduction}

This paper explores religious behaviour of a sample of Spanish Catholics, following Azzi and Ehrenberg's (AE's) (1975) pioneering model of religiosity and contributes to the comparative empirical literature in the economics of religion,

The great majority of the Spanish population is Catholic. According to data from the Spanish Bureau of Statistics, some $90 \%$ of the population are Catholics, about $1.5 \%$ have other religious affiliations and around $8.5 \%$ claim not to have any religion. These figures have been fairly stable since 1990 .

Many pupils in both the public and private Spanish education systems study "religion" at school as an optional course. ${ }^{1}$ In 1999/2000, out of a total of 3.619 million students enrolled in the Spanish education system (from primary schools to universities), over two-thirds $(68.6 \%)$ were enrolled in public schools, $23.6 \%$ in private Catholic schools and $7.8 \%$ in private non-Catholic schools. In the private Catholic schools, not surprisingly, almost all students (98.03\%) chose "religion" as an optional course. However, in the nonCatholic private schools, $84.96 \%$ also chose to study "religion;" and while the percentage was somewhat lower in the public schools, it was still high at $70.58 \%$ (official website statistics). In a survey of 12-to-16- year old pupils, asked why they preferred to study religion, over $50 \%$ claimed it was because they were Catholics. Among the other answers were: "It helps to improve my personality" (7.2\%); "My parents studied religion" (9.8\%); "It has a cultural impact" (9.9\%); and "I studied it before and liked it" (14\%).

Against this background of the Catholic affiliation of the great majority of the Spanish population and private schools, as well as the intensive study of religion in all schools, including the public education system, the following question arises: To what extent, if any, is this orientation reflected in the level of religiosity and religious beliefs?

\footnotetext{
${ }^{1}$ The other option is to study "ethics".
} 
Table 1 presents the data on beliefs in the representative sample used in our empirical study (see below). Respondents were asked about their beliefs in God, afterlife, heaven, hell and miracles. The results are shown separately for men and women. Women seem to exhibit significantly greater faith than men. The great majority of both men and women believe in God absolutely (67.72\% men and $82.89 \%$ women). However, around 50\% men either did not believe in or answered that they did not know about afterlife, heaven, hell and miracles. The pattern was significantly different for women: the majority believed in afterlife $(55.05 \%$ 'absolutely' or 'more or less'), heaven (53.58\%) and miracles (48.76\%). The corresponding figures for men are: $41.68 \%, 37.10 \%$ and $33.36 \%$. Both genders believed less in hell.

These data showing women to be more religious than men are in line with established findings in the psychology of religion (Beit Hallahmi, 1997), but the explanation for this is not clear.

Among the possible reasons are:

- Gender-based personality traits or, in economic terms, differences in taste for religiosity: women are more spiritual.

- Different socialization patterns - females are expected to engage more than men in congregational activities and supportive and nurturing "religious work."

- In their maternal role, women are the main guardians of cultural norms and traditions (including religion).

- Employment and wage rates and, consequently, the opportunity cost of time, are lower among women than men. Therefore, women allocate more time to religious activity. 
To summarize, the Spanish are highly affiliated with the Catholic church. However, although the great majority study religion, many of them, particularly the men, are not strong believers in the basic Catholic postulates.

A comparison of Americans and Spaniards gives the following unexpected finding: Although state and religion are separated and religion is not taught at school in the United States, Americans have stronger religious beliefs, particularly in God, than Spaniards. In a series of polls conducted over more than 50 years (since 1945; see Iannaccone, 1998), about 95\% Americans professed belief in "the existence of God or a universal spirit" and a considerable percentage believed in heaven, hell and afterlife. The corresponding figures for the present Spanish sample are significantly lower. Religious beliefs in the United States were stable over the years. Church membership rates have been on the rise over the past 200 years and now exceed 60\% (Iannaccone, 1998). Again, in the Spanish sample, attendance at church services is less frequent.

This paper is structured as follows: Section 2 presents a brief review of the literature on the economics of religion; Section 3 describes the data set, including a descriptive summary of the sample statistics; The results are analyzed in Section 4; and Section 5 concludes.

\section{Background - Economic Analysis of Religion}

Adam Smith (1965, first published in 1776) laid the foundations for the economic analysis of religion in the "The Wealth of Nations." According to him, the 'production' of religiosity is the same as that of goods, in the sense that, in churches, like firms, market forces operate; like the economy, religion benefits from competition; and, like producers, priests are motivated by self-interest. 
Two hundred years later, Azzi and Ehrenberg (1975) were the first to claim that religious behavior is motivated by rational choice. In a series of papers, Azzi and Ehrenberg (1975), Long and Settle (1977), Ehrenberg (1977), Ulbrich and Wallace (1983) and Neuman (1986) extended the New Home Economics (NHE) approach, pioneered by Mincer (1962, $1963)$ and Becker $(1960,1965)$. The NHE introduced the concept that all goods and services can be produced in a household and cost and income effects apply to a broad range of topics. Azzi and Ehrenberg formulated and empirically tested an economic theory of "religiosity" in which time devoted to religious activities is looked upon primarily as an investment in an expected stream-of-consumption benefit in an after-life (the "salvation motive"), with subsidiary contributions by the "consumption motive" (whereby individuals derive current satisfaction from religious practice either due to their inherent religious beliefs or for purely social reasons) and the "social-pressures motive" (participation in religious activity may enhance the prospects for business success). The first above-mentioned motive would be expected to lead to a positive relationship between age and time devoted to religious activity. This is because concentrating after-life investment in the later stages of the life-cycle would keep investment costs low since such individuals are temporally closer to the time when benefits would be expected to accrue. Moreover, since the possibility of death is an increasing function of age, individuals would tend to increase the amount of time spent in religious activity with age. Not only would those believing in after-life increase investment in religiosity with age, but risk-averse individuals who are unsure whether there is an afterlife might also do so (Rodero and Brañas, 2000). The second motive, which links religiosity with social behavior, subsequently led to club models of religion. Examples of such studies are: Sullivan (1985), Wallis (1990), Chiswick (1991) and Iannaccone (1992).

The third motive is utilitarian or materialistic behavior, in the sense that churches are meeting places where people interact with others, and thereby these places might serve to 
increase their career opportunities. Church attendance is one of many ways of building social capital (Sacerdote and Glaeser, 2001). This motive should be more dominant among working-age males and among highly educated individuals with more demanding careers.

While the last two motives offer a rationale for public religious behavior (such as church attendance), they do not explain private acts of religion, such as prayer, where only the "salvation motive" is relevant.

The main thrust of the literature in this field relates to empirical testing of AE's basic model rather than its theoretical extensions (Examples are: Neuman (1986), and GrossbardShechtman and Neuman (1986) - using Israeli data; Sullivan (1985) - using data for California; Barro and McCleary (2002) - using an international panel). ${ }^{2}$ The present paper also follows these lines.

While these papers focus on the demand for religiosity (by individuals or households) an alternative approach emphasizes the supply of religion by religious organizations. Religion is considered a market producing religious goods. Papers in this set address problems such as "free-riders" in religious clubs (Iannaccone, 1992); marketing strategies in religious firms (Dolin, Slesnick and Byrd, 1989; Sawkins and Paterson, 1996); monopolistic attitudes (Ekelund et al., 1996; Raskovich, 1996), monopolistic competition (Rodero and Brañas, 2000); profit-maximizing behavior (Iannaccone, 1998), and efficient financing of churches (Olds, 1994).

\section{Testable Hypotheses}

The theoretical models of religiosity presented by AE (1975), Neuman (1986) and Grossbard-Shechtman and Neuman (1986) are extensions of the seminal work of Mincer and

\footnotetext{
${ }^{2}$ Rodero et al. (2002) is a rare example of a theoretical extension of this model. Neuman (1986) and GrossbardShechtman and Neuman (1986) present theoretical insights along with empirical testing.
} 
Becker on time allocation in the household. Here time (and money) are allocated to religious activity. Several testable hypotheses can be derived from these models.

(1) Gender Differences: Men are expected to allocate less time to religious activity than women because they have a higher opportunity cost of time, due to higher labor force participation rates and higher wages. Women probably also have more taste for religiosity as indicated by different belief patterns (Table 1). Possible gender differences on various variables are discussed below.

(2) Schooling: The predicted effect of schooling on time devoted to religious activity is ambiguous. On the one hand, a negative effect would be expected - since the number of years of schooling proxies the cost of time, and economic theory predicts a negative relationship between the cost of time and the consumption of time-intensive goods, such as religious activity. A negative coefficient is also predicted by the "secularization thesis", according to which individuals become less religious and more sceptical of faith-based approaches as they acquire more education. This hypothesis dates back to Weber (1930). It is in accordance with Hume (1993, first published in 1757), who claimed that religion is based on irrational human fears and anxieties. He viewed religion as a mechanism used by people to ward off forces, that can't be explained rationally. Thus, the more educated and scientific people become, the more they would be inclined to reject beliefs reflecting superstition and supernatural forces. As the prominent sociologist Cerhard Lenski (1963) claimed, “... religion in the modern world is merely a survival from man's primitive past, and doomed to disappear in an era of science and enlightenment". The secularization hypothesis remains controversial (see: 
Finke and Stark, 1992; Iannaccone and Stark, 1994). Other theories predict a positive effect of schooling on religious activity. According to Sacerdote and Glaeser (2001), education increases the returns from networks and other forms of social capital. Hence, more educated people would participate more in group (including church) activities. Church attendance is one of many ways of building social capital. This explanation, which is similar to AE's social motive, would only be expected to be relevant for participation in mass. Barro and McCleary (2002) offer a different explanation, claiming that both religious belief and scientific work require a considerable degree of abstraction. Thus, more highly educated people who are more capable of abstract and scientific thought, would also be more able or willing to use such reasoning to support religious beliefs.

Thus, there is no clear-cut hypothesis regarding the effect of schooling on religious activity. However, all other things being equal, we would expect $a$ higher coefficient of schooling in participation in mass equations, which would be more pronounced for men, among whom the network effect is expected to be more prominent than for women.

(3) Age: A positive effect of age on time spent on religious activity (if the wage rate is controlled for) would be expected either due to habit formation (Neuman, 1986); concentrating afterlife investments in the later stages of the life-cycle (AE's salvation motive); or the cohort effect of decreasing tastes for religiosity over time (Ulbrich and Wallace, 1983). The social-network utilitarian effect should be evident mainly at the prime working age and predominantly among men, leading to high participation rates in mass among males in this age group. 
If the wage rate is not controlled for (to allow for changes in wage with advancing age), the age profile for religious activity is $U$-shaped, with a minimum point at the age at which wages reach a maximum and the opportunity cost of time is maximized (Azzi and Ehrenberg, 1975; Neuman, 1986).

(4) Marital Status: The individual's religious activities are likely to be positively related to marital status (and duration) and to the spouse's religiosity. This positive relationship between spouses' religious activity is expected to be strongest amongst educated people. This hypothesis is presented in Grossbard-Shechtman and Neuman (1986) and explained as the result of a process of investment in the partner. Such investment could be direct through formal or informal religious teachings, or indirect in the form of encouragement and making time available for religious practice. The level of such investment would be positively related to the duration of marriage, to the investor's religiosity level and to the spouse's education.

An alternative explanation for the above mentioned positive relationships could be a tendency for positive sorting. Religious partners may select each other to avoid potential conflict over values and marriages of such similar partners may last longer.

(5) Number of Children: We would expect a positive relationship between the number of children at home and religious activity, reflecting the parents' desire to instill religious heritage and values in the younger generation. This would be more pronounced in public religious activities.

(6) Exposure to Religious Activity: Children exposed to religious practices, either directly (by participating in prayer or mass) or indirectly by the personal example of their parents, would be expected to be more religiously active 
when they grow up, leading to inter-generational transmission of religious practices and values. If girls are closer to their mothers and boys to their fathers, women would presumably be more influenced in this respect by their mothers and men by their fathers.

\section{Data}

The database used in the present study was collected in 1998 by the Centro de Investigaciones Sociológicas CIS (Center for Sociological Research, Spain) under the International Social Survey Program: Religion, supported by UNESCO (CIS code \#2301), based on personal interviews. A total of 2488 interviews were carried out in cities or urban cores in all 47 Spanish provinces. After removing those with missing responses, 1361 valid (from 765 women and 590 men) questionnaires remained.

Almost 100\% respondents were Catholics and had Catholic spouses. However, they differed in level of religiosity, in terms of prayer habits and participation in mass. Women were more religious than men in both these dimensions of religiosity - mainly in prayer. On a scale from 1 to 10 (from 1 - never prays to 10 - prays once every day), the mean for women was 6.5 with a standard deviation of 3.2 and 4.8 for men (with the same standard deviation). ${ }^{3}$ Men and women were more similar in their participation in mass: on a scale from 1 to 6 (from 1 - never participates to 6 - participates every week): women had a mean of 3.7 and men 3.1 (both with the same standard deviation of 1.8). These gender differences can be explained by different tastes for religiosity, differences in socialization and/or lower cost of time among females. Women work less, are at home more and, therefore, spend more time in prayer and also in church attendance. The difference is smaller for the latter since men place more value on the social and career opportunities provided by church attendance.

\footnotetext{
${ }^{3}$ We treated both of these as continuous variables, implicitly assuming equal distances between successive values. We could have used the relative frequencies of dummy variables for the different levels, which would have been more accurate but would have given too many data rather than one central value.
} 
Sample characteristics are presented in Appendix Table 1, followed by a brief description.

\section{Estimation of Religiosity Equations}

As noted above, the great majority of Spanish men and women believe in God and a significant proportion participate in prayer and mass. To what extent is religious behaviour related to socio-economic variables, such as gender, schooling, age, income, number of children at home and religious exposure during childhood (up to the age of 12)?

To test our hypotheses and answer these questions, we estimated "religiosity equations". The dependent variable is religiosity level, proxied either by prayer or participation in mass, and the independent variables include the set of socio-economic variables listed above. Two alternative religiosity equations were estimated: an ordered logit and a two-outcome logistic model. Ordered logit models are used to estimate relationships between an ordinal dependent variable and a set of independent variables. Such a model is appropriate because both our alternative dependent variables are categorical and ordered from low to high (prayers: 'never prays' to 'once a day' - 10 categories; mass: 'never participates' to 'every week' - 6 categories). The two-outcome logistic model, with an arbitrary dichotomization ${ }^{4}$, simplifies the results but uses less information and, therefore, is less suitable. The Ordinary Least Squares, which treats the ordinal variable as continuous, is another, even less appealing alternative. The problem is that the gaps between successive values are not equal and, therefore, changing labeling (e.g., to 20 for 'prays every day') would give different results.

\footnotetext{
${ }^{4}$ For example: The dependent variable 'prayer' took on the value 1 if the answer was greater or equal to 6 (in a range of 1-to-10) and 0 otherwise. The dependent variable 'mass' took on the value of 1 if the answer was greater or equal to 4 (in a range of 1-to-6) and 0 otherwise.
} 
Table 2 presents the results of the Ordered Logit regressions, ${ }^{5}$ whereby an underlying score is estimated as a linear function of the independent variables and a set of cut points. The probability of observing outcome $i$, which corresponds to the estimated linear function, plus a random error, is within the range of the cut points estimated for the outcome:

$$
\operatorname{Pr}\left(\text { outcome }_{j}=i\right)=\operatorname{Pr}\left(k_{i}-1<\beta_{1} x_{1 j}+\beta_{2} x_{2 j}+\ldots+\beta_{k} x_{k j}+u_{j} \leq k_{i}\right), i=1 \ldots I \text { where } u_{j}
$$

is assumed to be logistically distributed. In either case, the coefficients $\beta_{1}, \beta_{2}, \ldots, \beta_{k}$ along with the cut points $k_{1}, k_{2}, \ldots, k_{I-1}$, are estimated, where $I$ is the number of possible outcomes and $k_{0}$ is taken as $-\infty$ and $k_{I}$ as $+\infty$.

The coefficients of the Ordered Logit estimation cannot readily be interpreted, but could be the estimated marginal effects of each variable on the unobserved latent variable from which the ordered outcomes are derived. However, such marginal effects include normalizing the error variance, which is not identified, to 1.

Regressions were estimated for men and women separately and also for the combined sample. The regression of the pooled sample includes, in addition to the socio-economic variables listed above, also a dummy variable for males and interactions of 'male' with all explanatory variables. This enables us to test the significance of the differential gender effects. Unlike most empirical studies on religiosity determinants (proxied by church attendance), we have data on two different measures of religiosity: (i) Frequency of participation in mass ( 6 categories) and (ii) Frequency of prayer (10 categories $)^{6}$. The first is a public activity, for which social and utilitarian motives are relevant, while the second is conducted privately at home and only reflects AE's salvation motive. Comparing the effects

\footnotetext{
${ }^{5}$ We also tried a simultaneous model, in which religiosity level, years of schooling and number of children (at home) were treated as simultaneously determined endogenous variables, the coefficients of the religiosity equations were only marginally affected.

${ }^{6}$ We also experimented with the sum of these two activities, however, the results of this regression equation did not add any interesting information.
} 
of various socio-economic variables on these two different dimensions might improve our understanding of religious behaviour. We did not have any data on church contributions or other expenses associated with religiosity, and, therefore, could not examine this aspect and the trade-off between time and money allocated to religious activity.

We now turn to the effects of various explanatory variables on religious activity, namely, gender, age, schooling, marital status, number of children, and exposure to religious activity during childhood (personal and family monthly incomes had no significant effects on any equations and were therefore dropped).

Gender: As the equation for the joint sample indicates, men pray less (with a coefficient of -0.825 ) and participate less frequently in mass (with a coefficient of -1.107$){ }^{7}$ These findings support our first hypothesis. Higher church attendance among women is found in numerous other studies (e.g., Azzi and Ehrenberg, 1975; Ulbrich and Wallace, 1983; Iannaccone, 1998). Gender might also affect the magnitude (and direction) of various socioeconomic variables. This is indicated by interaction terms and is discussed below.

$\underline{\text { Age: }}$ Both types of religious activity basically increase with age, for both genders. A major increase is evidenced over the age of 60 , when opportunity time costs are low and, more importantly, the salvation motive is expected to be more dominant. Cohort effects might also be at work. Our data set did not include any information on wage rates. Years of schooling are a partial proxy for this missing variable and, therefore, our regressions only partially control for the wage rate. When we experimented with personal or family monthly income as explanatory variables, we found that the coefficients for these variables were not significant. ${ }^{8}$

Only Neuman (1986) used a more informative and detailed religiosity measure, surveying information on number of hours per year devoted to a series of religious activities.

${ }^{7}$ When interaction terms are not included the coefficients are $-1.011(t=9.99)$ for prayer and $-0.716(t=6.93)$ for church attendance. The difference between men and women is now more pronounced for prayer. In the case of church attendance, the social and practical motives, that are expected to be more important for men than women, reduce the difference between the genders.

${ }^{8}$ This might be a result of the inaccurate measure of wage rate (proxied by income intervals). .Also, when income is included the number of observations drops significantly due to many missing values. 
The AE model predicts declining religious activity at younger ages, when wages rise most, leading to a U-shaped age-religiosity profile (if the wage rate is not controlled for). This was found in some empirical studies (e.g., Neuman, 1986). One of our regressions, namely the regression of participation in mass for men, also indicates this pattern. Going from the 31-to-45 to the 46-to-60 age group, we observed a decline in mass participation, in contrast to a steady increase with age in all other regressions.

A comparison of age profiles by gender, shows that female profiles are steeper than the male profiles for both prayer and mass and participation, i.e., the increase (as age advances) is faster for women. However, as regressions (5) and (6) demonstrate the differences are significant for 2 out of the 6 time points (prayer - over 60; mass participation -46 to 60$)$.

Years of Schooling: The effect of schooling is positive and marginally significant (at $\alpha=0.10$ ) for women and for men's participation in mass. ${ }^{9}$ Years of schooling have no significant effect on men's prayer. Our hypothesis (2) would predict an ambiguous result due to the conflicting effects of schooling. In the case of male public activity, the network effect dominates, leading to a positive effect that does not exist for prayer. The results in the literature are also mixed. Ulbrich and Wallace (1983) and Iannaccone (1998) found, using US data, that education is generally a positive predictor of religiosity. Barro and McCleary (2002), had similar results using an international data set.

In a sample of Israelis, Neuman (1986) found a negative effect of schooling on time devoted to religious activity among Jewish males. The different empirical result might stem from a better definition of the dependent variable. A possible major shortcoming with the available empirical studies is the lack of a measure for time spent by individuals on religious

\footnotetext{
${ }^{9}$ To test for a non-monotonic effect of schooling we added schooling squared as an independent variable. The coefficient of the squared variable was insignificant and was therefore omitted.
} 
activities - a potential serious lacuna, given that the models set out to explain precisely this variable. Instead, the use of partial proxy measures (usually frequency of church attendance and, in our case, also of prayer) raises questions about the generality of the results, particularly since such proxy measures represent only one dimension of religiosity. Neuman (1986) used time allocated to religious activity as a measure of time, which conforms more closely to the dependent variable specified in AE's theoretical model. This was measured by the total number of hours per year devoted by respondents to various religious activities. Using this as the independent variable, she found a negative effect of education on time allocated to religious activity.

Another possible reason for the marginally positive (or lack of significant) relationship between education and religiosity in Spain, compared to the negative relationship in Israel, might be the different structures of the education systems. In Israel, there is a basic conflict of interest between formal secular education and religion. The more religious sectors tend to avoid formal education. By contrast, in Spain, the formal education system was originally developed by the Catholic church. All private universities and most private high schools are Catholic. They are known for their excellence and entrance is limited to the best students, often from wealthy families. These private schools are also more successful in inculcating Catholic values. Religion is an optional subject even in public schools. Moreover, under Franco's dictatorship (until 1975), when many of our respondents were at school, Catholic religious studies were compulsory in both the private and public education systems. This strong relationship between Catholicism and education most probably explains the observed positive (or lack of significant) effect of education on religiosity in our Spanish sample.

Marital Status: To test our hypothesis on the positive effect of a religious spouse on the individual's religious behavior we used an interaction term married*spouse catholic. Our 
data set does not provide information on the spouse's religious activity (prayer and mass participation) and we therefore used the catholic denomination as proxy for a higher level of religiosity. Lack of data on duration of marriage did not allow us to check whether this positive relationship grows with marriage duration.

Another, indirect proxy for level of religiosity is gender. Women in our sample are more religious than men and we would therefore expect to see a stronger positive effect of the wife on her husband than the other way. ${ }^{10}$

As the results in Table 2 indicate, a catholic wife has a substantial positive effect on the husband's participation in mass $(0.798, \mathrm{t}=3.73)$ and a marginally significant positive effect on time her husband devoted to prayer $(0.338, \mathrm{t}=1.63)$. Catholic men, do not affect the wife's religious behavior. Women married to catholic men, neither pray more nor participate more in mass compared to women who are not married or are married to men who are not catholic. As expected, we therefore observe a gender difference in the cross effect on religiosity of the spouse. This is also indicated by the pooled regression where only male*married*spouse catholic was significant.

The effect of a catholic spouse was not significantly stronger for more educated individuals. ${ }^{11}$ Our hypothesis (4) is therefore partially supported. We do find a cross-effect, only for men affected by women but this effect is not enhanced by the respondent's educational level.

Number of Children: The number of children at home had a positive significant effect on male mass participation and no significant effects in all other cases. Men from families with

\footnotetext{
${ }^{10}$ Gender differences might have alternative explanations as well, such as: women invest more in their partners than men in their wives; women are morally superior over them (see, Cameron, 2001).

${ }^{11}$ The interaction term married*spouse catholic*schooling was insignificant when added to regressions (1) (4). Also, the coefficients of "married" and of "spouse catholic" were insignificant and were therefore omitted.
} 
more children at home went to church more frequently (often with the children, in whom they wish to inculcate these values). This partially supports our hypothesis (5).

Exposure to Religious Activity During Childhood: To check for inter-generational effects on religiosity, we used the following 3 independent variables: church attendance of the respondent at 12 years of age (which ranged from never (1) to few time a week (9)) and of his mother and father (the same 9 categories). As Table 2 shows, an individual's religiosity was positively and significantly related to exposure to church attendance during childhood. This is true for all regressions. In most cases, it is also positively related to the parents' religious behaviour. Interestingly, while women were more affected by their mothers, men were influenced mainly by their fathers. These findings indicate the importance of the personal example, personal experience and parental education at home and support hypothesis (6) above.

\section{Summary and Conclusions}

The empirical study of religious activity is an emerging field in economics. This paper is the first attempt to analyze the religiosity among the Spanish population, thereby adding to the growing body of country-specific empirical studies. Towards this end, we analyzed tastes in religiosity and estimated religiosity equations, using two dimensions of religiosity: prayer and participation in mass.

Economic and sociological theories predict gender differences in religious behaviour and beliefs. Therefore, we study the genders separately and include gender and interactions with gender in our pooled regressions. Data on beliefs in God, afterlife, heaven, hell and miracles, for both groups, lead to the following conclusions (Table 1):

- Women exhibited much higher levels of belief than men in all Catholic postulates; 
- The majority of men and women believed absolutely in God;

- A significantly larger percentage of men did not believe in afterlife, hell, heaven or miracles.

- While they are affiliated with the Catholic church and study religion at school, the Spaniards (particularly the men) are not firm believers in the basic Catholic postulates.

As in numerous other empirical studies, we also found religiosity to be affected by socio-economic variables. An Ordered Logit estimation of religiosity equations (proxied by church attendance and prayer) gave the following results:

- Compared to women, men prayed less and participated less frequently in mass.

- Religious activity increased with age and was more marked with advancing age. Age profiles were steeper for women than for men. Male participation in mass exhibited a U-shaped tendency.

- There is a positive (marginally significant) relationship between education and female religious activities and between male church attendance and level of education.

- Being married to a catholic spouse has a positive effect on men's participation in mass (but not on prayer). Women are not affected by a catholic husband.

- There is a positive relationship between male participation in mass and number of children at home, but no significant relationship to any other dependent variables.

- Religiosity of both men and women is positively affected by exposure to religious activity during childhood. 
In conclusion, age and exposure during childhood seem to be the most important determinants of religiosity in the Spanish case. Education has a marginal positive effect. The salvation motive apparently provides a better explanation for religious behaviour, while the professional utilitarian motive also seems to be present behind the male religious behaviour. Men view church attendance as another way of building social capital, thereby enhancing career opportunities. 


\section{References}

Azzi, Corry and Ronald G. Ehrenberg. 1975. "Household Allocation of Time and Church Attendance," Journal of Political Economy; 83:1, pp. 27-56.

Barro, Robert, J. and Rachel M. McCleary. 2002. "Religion and Political Economy in an International Panel,” NBER Working Paper no. 8931.

Becker, Gary S. 1960. “An Economic Analysis of Fertility," in Demographic and Economic Change in Developing Countries. Coale et al., ed., Princeton: Princeton University Press, pp. 209-240.

Becker, Gary S. 1965. "A Theory of Allocation of Time," Economic Journal, 85, pp. 493517.

Beit-Hallahmi, Benjamin. 1997. "Biology, Density and Change: Women's Religiosity and Economic Development," Journal of Institutional and Theoretical Economics, 166-178.

Cameron, H. 2001. "A Perspective from the Study of Religious Organisations". in Organisational Theory and the Non-Profit Form: Proceedings of a Seminar Series at the LSE Centre for Civil Society. H.K. Anheier, ed., London, CCS, LSE: pp. 52-61.

Chiswick, Barry R. 1991. "An Economics Analysis of Philanthropy," in Contemporary Jewish Philanthropy in America. Barry A. Kosmin and Paul Ritterband, eds., Savage, MD: Roman Ex Littlefield, pp. 3-15.

Dolin, Richard A., Frank Slesnick and John T. Byrd. 1989. "The Organizational Structures of Church and Orthodoxy." Paper presented at meetings of West. Econ. Assoc., Lake Tahoe, NV.

Ehrenberg, Ronald G. 1977. "Household Allocation of Time and Religiosity: Replication and Extension," Journal of Political Economy, 85:2, pp. 415-23.

Ekelund, Robert B. et al. 1996. Sacred Trust: The Medieval Church as an Economic Firm. New York: Oxford U. Press.

Finke, R. and R. Stark. 1992. The Churching of America 1776-1990, New Brunswick Nj, Rutgers University Press.

Grossbard-Shechtman, Shoshana Amyra and Shoshana Neuman. 1986. "Economic Behavior, Marriage and Religiosity," Journal of Behavioral Economics, 15, pp. 71-86.

Hume, David. [1757] 1993. The Natural History of Religion, edited by J.C.A. Gaskin, Oxford, Oxford University Press, 1993.

Iannaccone, Laurence R. 1992. "Sacrifice and Stigma: Reducing Free-Riding in Cults, Communes, and Other Collectives," Journal of Political Economy, 100:2, pp. 271-97. 
1998. "Introduction to the Economics of Religion," Journal of Economic Literature, 36:1465-1496.

Iannaccone, Laurence R. and R. Stark. 1994. "A Supply-Side Reinterpretation of the 'Secularization' of Europe," Journal of the Scientific Study of Religion, March, 76-88.

Lenski, Gerhard E. 1963. The Religious Factor. Rev. ed. Garden City, NY: Doubleday.

Lehrer, Evelyn L. 1996. "Religion as a Determinant of Marital Fertility," Journal of Population Economics, 9. pp. 173-196.

Long, Stephen H. and Russell F. Settle. 1977. "Household Allocation of Time and Church Attendance: Some Additional Evidence," Journal of Political Economy, 85:2, pp. 409-13.

Mincer, Jacob. 1962. "Labor Force Participation of Married Women: A Study of Labor Supply," in Aspects of Labor Economics edited by H. Gregg Lewis. Princeton, N.J.: Princeton University Press.

Mincer, Jacob. 1963. "Market Prices, Opportunity Costs, and Income Effects." in Measurement in Economics: Essays in Honor of Yehuda Grunfeld. Carl F. Christ, ed., Stanford, CA: Stanford University Press.

Neuman, Shoshana. 1986. "Religious Observance within a Human Capital Framework: Theory and Application," Applied Economics, 18:11, pp. 1193-202.

Olds, Kelly. 1994. "Privatizing the Church: Disestablishment in Connecticut and Massachusetts,” Journal of Political Economy, 102:2, pp. 277-97.

Raskovich, Alexander. 1996. "You Shall Have No Other Gods Besides Me: A LegalEconomic Analysis of the Rise of Yahweh," Journal of Institutional and Theoretical Economics, 152:3, pp. 449-71.

Rodero, Javier and Pablo Brañas. 2000. "Hotelling and the Olympus: Modelling Differences in Religious Prices," Central European Journal of Operation Research, pp. 265-283.

Rodero, Javier, Pablo Brañas, Adrian Gourlay and Alejandro Lorca. 2002. "Believe or not Believe: Generalising the Azzi-Ehrenberg Model," Cuadernos de Economía, forthcoming.

Sacerdote, Bruce and Edward L. Glaeser. 2001. "Education and Religion", NBER working paper no. 8080, January.

Sawkins John and Ian Paterson. 1996. "An Occupational Analysis of Methodist Local Preachers in Scotland," mimeo, Department of Economics, Heriot-Wattt University, DP 96/18.

Smith, Adam. [1776]1965. An Inquiry into the Nature and Causes of the Wealth of Nations. New York: Modern Library. 
Sullivan, Dennis H. 1985. "Simultaneous Determination of Church Contributions and Church Attendance," Economic Inquiry, 23:2, pp. 309-20.

Ulbrich, Holley and Myles Wallace. 1983. "Church Attendance, Age, and Belief in the Afterlife: Some Additional Evidence," Atlantic Economic Journal, 11:2, pp. 44-51.

Wallis, Joe L. 1990. "Modelling Churches as Collective Action Groups," International Journal of Social Economics, 17:1, pp. 59-72.

Weber, Max. 1930. The Protestant Ethic and the Spirit of Capitalism, translated by Talcott Parson, London, Allen \& Unwin.

http://www.conferenciaepiscopal.es/estadisticas/RELIGION.htm

http://www.conferenciaepiscopal.es/enseuanza/esstadisticas/religion2000.htm 
TABLE 1:

Religious Beliefs by Gender Among Spanish Women and Men, 1998

\begin{tabular}{|l|c|c|c|c|c|}
\hline & \multicolumn{5}{|c|}{ Women - Do you believe in... } \\
\hline & God & Afterlife & Heaven & Hell & Miracles \\
\hline Absolutely & $\mathbf{8 2 . 8 9}$ & $\mathbf{2 7 . 9 9}$ & 25.82 & 19.13 & 21.93 \\
\hline More or less & 1.40 & 27.06 & $\mathbf{2 7 . 7 6}$ & 19.98 & $\mathbf{2 6 . 8 3}$ \\
\hline Not much & 6.22 & 11.51 & 12.13 & 17.34 & 15.16 \\
\hline Not at all & 4.74 & 19.98 & 22.63 & $\mathbf{3 1 . 3 4}$ & 25.97 \\
\hline Don't know/Did not answer & 4.75 & 13.46 & 11.66 & 12.21 & 10.11 \\
\hline \hline & & Men - Do you believe in ... \\
\hline & God & Afterlife & Heaven & Hell & Miracles \\
\hline Absolutely & $\mathbf{6 7 . 7 2}$ & 19.55 & 18.05 & 12.56 & 13.48 \\
\hline More or less & 1.91 & 22.13 & 19.05 & 14.23 & 19.88 \\
\hline Not much & 10.65 & 12.65 & 14.89 & 16.89 & 14.89 \\
\hline Not at all & 12.48 & $\mathbf{3 4 . 5 3}$ & $\mathbf{3 7 . 8 5}$ & $\mathbf{4 5 . 5 1}$ & $\mathbf{4 1 . 5 1}$ \\
\hline Don't know/Did not answer & 2.24 & 11.14 & 10.16 & 10.81 & 10.24 \\
\hline
\end{tabular}

Notes:

- Sample sizes are: 765 women and 590 men.

- Numbers in bold refer to the higher values. 
TABLE 2:

Ordered Logit Religiosity Functions by Gender Among Spanish Women and Men, 1998

\begin{tabular}{|c|c|c|c|c|c|c|}
\hline \multirow{2}{*}{ Independent } & \multicolumn{2}{|c|}{ Women } & \multicolumn{2}{|c|}{ Men } & \multicolumn{2}{|c|}{ Total } \\
\hline & $\begin{array}{c}(1) \\
\text { Prayer }\end{array}$ & $\begin{array}{c}(2) \\
\text { Mass }\end{array}$ & $\begin{array}{c}\text { (3) } \\
\text { Prayer }\end{array}$ & $\begin{array}{c}\text { (4) } \\
\text { Mass }\end{array}$ & $\begin{array}{c}\text { (5) } \\
\text { Prayer }\end{array}$ & $\begin{array}{c}(6) \\
\text { Mass }\end{array}$ \\
\hline Years of Schooling & $\begin{array}{l}0.026 \\
(1.68)\end{array}$ & $\begin{array}{l}0.025 \\
(1.64)\end{array}$ & $\begin{array}{l}0.008 \\
(0.46)\end{array}$ & $\begin{array}{l}0.027 \\
(1.63)\end{array}$ & $\begin{array}{l}0.026 \\
(1.69)\end{array}$ & $\begin{array}{l}0.025 \\
(1.60)\end{array}$ \\
\hline \multicolumn{7}{|l|}{ Age Groups (years) } \\
\hline $31-$ to-45 & $\begin{array}{l}0.205 \\
(1.06)\end{array}$ & $\begin{array}{l}0.401 \\
(2.04)\end{array}$ & $\begin{array}{l}0.209 \\
(0.85)\end{array}$ & $\begin{array}{l}0.337 \\
(1.37)\end{array}$ & $\begin{array}{l}0.205 \\
(1.06)\end{array}$ & $\begin{array}{l}0.391 \\
(2.01)\end{array}$ \\
\hline $46-$ to- 60 & $\begin{array}{l}1.001 \\
(4.52)\end{array}$ & $\begin{array}{l}1.106 \\
(4.91)\end{array}$ & $\begin{array}{l}0.357 \\
(1.24)\end{array}$ & $\begin{array}{l}0.095 \\
(0.33)\end{array}$ & $\begin{array}{l}0.999 \\
(4.54)\end{array}$ & $\begin{array}{l}1.063 \\
(4.78)\end{array}$ \\
\hline Over- 60 & $\begin{array}{l}1.770 \\
(7.02)\end{array}$ & $\begin{array}{l}1.739 \\
(6.88)\end{array}$ & $\begin{array}{l}1.024 \\
(3.35)\end{array}$ & $\begin{array}{l}1.228 \\
(3.94)\end{array}$ & $\begin{array}{l}1.772 \\
(7.09)\end{array}$ & $\begin{array}{l}1.674 \\
(6.74)\end{array}$ \\
\hline Married * Spouse Catholic & $\begin{array}{l}0.129 \\
(0.86)\end{array}$ & $\begin{array}{l}0.092 \\
(0.60)\end{array}$ & $\begin{array}{l}0.338 \\
(1.63)\end{array}$ & $\begin{array}{l}0.798 \\
(3.73)\end{array}$ & $\begin{array}{l}0.130 \\
(0.87)\end{array}$ & $\begin{array}{l}0.090 \\
(0.59)\end{array}$ \\
\hline Number of Children at Home & $\begin{array}{l}0.027 \\
(0.56)\end{array}$ & $\begin{array}{l}-0.026 \\
(0.53)\end{array}$ & $\begin{array}{l}0.079 \\
(1.40)\end{array}$ & $\begin{array}{l}0.135 \\
(2.36)\end{array}$ & $\begin{array}{l}0.027 \\
(0.56)\end{array}$ & $\begin{array}{l}-0.026 \\
(0.53)\end{array}$ \\
\hline Participation in Mass During Childhood & $\begin{array}{l}0.178 \\
(4.40)\end{array}$ & $\begin{array}{l}0.157 \\
(3.85)\end{array}$ & $\begin{array}{l}0.190 \\
(4.54)\end{array}$ & $\begin{array}{l}0.138 \\
(3.29)\end{array}$ & $\begin{array}{l}0.179 \\
(4.54)\end{array}$ & $\begin{array}{l}0.154 \\
(3.80)\end{array}$ \\
\hline $\begin{array}{l}\text { Participation in Mass of Mother During } \\
\text { Respondent's Childhood }\end{array}$ & $\begin{array}{l}0.111 \\
(2.83)\end{array}$ & $\begin{array}{l}0.173 \\
(4.32)\end{array}$ & $\begin{array}{l}0.063 \\
(1.35)\end{array}$ & $\begin{array}{l}0.083 \\
(1.76)\end{array}$ & $\begin{array}{l}0.112 \\
(2.86)\end{array}$ & $\begin{array}{l}0.169 \\
(4.28)\end{array}$ \\
\hline $\begin{array}{l}\text { Mass Participation of Father During } \\
\text { Respondent's Childhood }\end{array}$ & $\begin{array}{l}0.001 \\
(0.03)\end{array}$ & $\begin{array}{l}0.075 \\
(2.32)\end{array}$ & $\begin{array}{l}0.066 \\
(1.68)\end{array}$ & $\begin{array}{l}0.168 \\
(4.21)\end{array}$ & $\begin{array}{l}0.000 \\
(0.01)\end{array}$ & $\begin{array}{l}0.071 \\
(2.22)\end{array}$ \\
\hline Male & - & - & - & - & $\begin{array}{r}-0.825 \\
(1.58) \\
\end{array}$ & $\begin{array}{l}-1.107 \\
(2.10) \\
\end{array}$ \\
\hline $\begin{array}{l}\text { Interactions of Male with: } \\
\text { Years of Schooling }\end{array}$ & - & - & - & - & $\begin{array}{c}-0.018 \\
(0.80) \\
\end{array}$ & $\begin{array}{l}0.003 \\
(0.13) \\
\end{array}$ \\
\hline \multicolumn{7}{|l|}{ Age Groups (years) } \\
\hline $31-$ to-45 & - & - & - & - & $\begin{array}{r}-0.001 \\
(0.00)\end{array}$ & $\begin{array}{l}-0.040 \\
(0.13)\end{array}$ \\
\hline $46-$ to- 60 & - & - & - & - & $\begin{array}{r}-0.641 \\
(1.77)\end{array}$ & $\begin{array}{l}-0.961 \\
(2.62)\end{array}$ \\
\hline Over- 60 & - & - & - & - & $\begin{array}{l}-0.750 \\
(1.91)\end{array}$ & $\begin{array}{c}-0.383 \\
(0.97)\end{array}$ \\
\hline Married * Spouse Catholic & - & - & - & - & $\begin{array}{l}0.203 \\
(0.79) \\
\end{array}$ & $\begin{array}{l}0.732 \\
(2.78) \\
\end{array}$ \\
\hline Number of Children at Home & - & - & - & - & $\begin{array}{l}0.050 \\
(0.67)\end{array}$ & $\begin{array}{l}0.164 \\
(2.18)\end{array}$ \\
\hline
\end{tabular}




\begin{tabular}{|c|c|c|c|c|c|c|}
\hline $\begin{array}{l}\text { Participation in Mass During } \\
\text { Childhood }\end{array}$ & - & - & - & - & $\begin{array}{l}0.011 \\
(0.19)\end{array}$ & $\begin{array}{l}0.011 \\
(0.19)\end{array}$ \\
\hline $\begin{array}{l}\text { Participation in Mass of } \\
\text { Mother During Respondent's } \\
\text { Childhood }\end{array}$ & - & - & - & - & $\begin{array}{r}-0.050 \\
(0.82)\end{array}$ & $\begin{array}{l}-0.086 \\
(1.39)\end{array}$ \\
\hline $\begin{array}{l}\text { Mass Participation of Father } \\
\text { During Respondent's } \\
\text { Childhood }\end{array}$ & - & - & - & - & $\begin{array}{l}0.065 \\
(1.31)\end{array}$ & $\begin{array}{l}0.105 \\
(2.04)\end{array}$ \\
\hline Pseudo $\mathrm{R}^{2}$ & 0.0551 & 0.0940 & 0.0394 & 0.0798 & 0.0634 & 0.0938 \\
\hline Sample size & 765 & 765 & 590 & 590 & 1355 & 1355 \\
\hline
\end{tabular}

Notes:

- Numbers in parentheses are t-statistics.

- The following were the possible responses for the variable "Prayer:" (1) never prays; (2) once a year; (3) twice a year; (4) few times a year; (5) once a month; (6) two or three times a month; (7) almost every week; (8) every week; (9) several times a week; (10) once a day.

- The following were the possible responses for the variable "Mass:" (1) never participates; (2) once a year; (3) twice a year; (4) once a month; (5) two or three times a month; (6) every week.

- The following were the possible responses for the variables "Participation in Mass During Childhood", "Participation in Mass of Mother" and "Participation in Mass of Father:" (1) never participated; (2) once a year; (3) two times a year; (4) several times a year; (5) once a month; (6) two or three times a month; (7) almost every week; (8) every week; (9) several times a week.

- Estimated using STATA 7. The 'cut points' of each of the regressions are not presented to save space. 


\section{APPENDIX: Sample Characteristics}

As Table 1 in the Appendix shows, the respondents were heterogeneous in terms of age and education, reflecting the diversity of the Spanish population. About $25 \%$ of both men and women fell into each age group: 18-to-30; 31-to-45; 46-to-60 and over 60. The average age was 45 , ranging from 18 to over 90, with similar distributions for both genders.

The men were slightly more educated than the women. The mean years of schooling were 10.3 for men and 9.7 for women, with a standard deviation of around 5 for both groups. This is also reflected in the distribution by formal education level - $16 \%$ women and $13 \%$ men did not complete primary education, while $36 \%$ women, compared to $41 \%$ men, had some academic education (including college, polytechnic and university). The percentages of primary- and secondary-school graduates were similar for men and women (around 25\% of the men and women in each group). ${ }^{12}$

About $67 \%$ men and women in the survey were married and the average number of children at home was 1.9 , ranging from 0 to $12 .{ }^{13}$

As evidenced in many other countries, women earned less than men. Men and women in our sample had a similar age distribution and the men were only slightly more educated than the women. Yet we found more men than women in the higher monthly income intervals: $9.7 \%$ men and $6.7 \%$ women had monthly incomes between 200 and 500 thousand pesetas. A mere $0.6 \%$ men and $0.3 \%$ women earned more than 500 thousand pesetas. The great majority of women $(70.6 \%)$ earned less than 100 thousand pesetas compared to $37.3 \%$ men. This group included respondents who did not participate in the

\footnotetext{
${ }^{12}$ Among 15 European countries, Spain ranked second from last, and Portugal last (at 37.7\%) in percentage of population (aged 25-to-59) with at least a secondary-school education. Germany ranked first with $81.6 \%$.

${ }^{13}$ Lehrer (1996) predicted that spouses with the same religious affiliation would have lower divorce rates and more children than couples with different religious affiliations. This hypothesis is not supported by our data: while in the great majority of couples, both spouses were both Catholics, they had low fertility rates.
} 
labor force. The majority of men $(52.3 \%)$ have a monthly income ranging from 100-to-200 thousand pesetas. The parallel figure for women is $22.4 \%$.

The monthly family income distribution was quite similar for men and women in our sample. About $50 \%$ incomes were in the 100 -to-200-thousand peseta range, a mere $2 \%$ over 500 thousand pesetas and about $25 \%$ each were in the under-100- and 200-to-500-thousand peseta range. Comparing the distribution of personal versus family income, only women in the latter group 'moved up,' reflecting the fact that a significant proportion either work parttime or not all. 
APPENDIX TABLE 1: Sample Characteristics by Gender Among Spanish Women and Men, 1998

\begin{tabular}{|l|c|c|}
\hline \multicolumn{1}{|c|}{ Variables } & Women & Men \\
\hline Prayer (1-10) & $6.530(3.22)$ & $4.806(3.21)$ \\
\hline Mass (1-6) & $3.704(1.80)$ & $3.128(1.81)$ \\
\hline Catholic (\%) & 99.349 & 99.663 \\
\hline Spouse Catholic (\%) & 97.654 & 94.180 \\
\hline Participation in Mass During Childhood (1-10) & $6.845(2.03)$ & $6.518(2.18)$ \\
\hline Mother's Participation in Mass During the & $6.174(2.40)$ & $6.448(2.15)$ \\
Respondent's Childhood (1-9) & & \\
\hline Father's Participation in Mass During the & $4.829(2.72)$ & $5.133(2.56$ \\
Respondent's Childhood (1-9) & & \\
\hline Years of Schooling & $9.717(5.52)$ & $10.344(5.34)$ \\
\hline Formal Education (\%) & & \\
Did not complete primary & 16.276 & 12.816 \\
Primary & 25.260 & 23.609 \\
Secondary & 22.396 & 22.766 \\
Academic & 36.068 & 40.809 \\
\hline Age (years) & $44.781(18.15)$ & $44.971(18.22)$ \\
\hline Age Groups (in years) (\%) & 28.906 & \\
18-to-30 & 25.651 & 26.307 \\
31-to-45 & 21.224 & 23.656 \\
46-to-60 & 24.219 & 22.934 \\
Over-60 & $1.889(4.55)$ & $1.882(1.54)$ \\
\hline Number of Children at Home & & \\
\hline Monthly Personal Income (in thousands of & 70.639 & 37.323 \\
pesetas) (\%) & 22.384 & 52.333 \\
Less than 100 & 6.686 & 9.736 \\
Between 100 and 200 & 0.291 & 0.608 \\
Between 200 and 500 & & \\
Over 500 & 30.256 & 23.725 \\
\hline Monthly Family Income (in thousands of & 46.667 & 48.824 \\
pesetas) (\%) & 20.684 & 25.490 \\
Less than 100 & 60.677 & 1.961 \\
Between 100 and 200 & 765 & 64.418 \\
Between 200 and 500 & & 590 \\
Over 500 & & \\
\hline Married (\%) & & \\
\hline Sample size & & \\
\hline
\end{tabular}

Notes:

Numbers in parentheses are standard deviations.

The following were the possible responses for the variable "Prayer:" (1) never prays; (2) once a year; (3) twice a year; (4) few times a year; (5) once a month; (6) two or three times a month; (7) almost every week; (8) every week; (9) several times a week; (10) once a day.

The following were the possible responses for the variable "Mass:" (1) never participates; (2) once a year; (3) twice a year; (4) once a month; (5) two or three times a month; (6) every week.

- The following were the possible responses for the variables "Participation in Mass During Childhood," "Mother's Participation in Mass During the Respondent's Childhood" and "Father's Participation in Mass the Respondent's Childhood:" (1) never participated; (2) once a year; (3) two times a year; (4) several times a year; (5) once a month; (6) two or three times a month; (7) almost every week; (8) every week; (9) several times a week.

- The means of Monthly Family Income were based on smaller samples due to missing data (585 women and 510 men).

- The means of Monthly Personal Income were based on even smaller samples due to missing data (344 women and 493 men). 


\section{IZA Discussion Papers}

\begin{tabular}{|c|c|c|c|c|}
\hline No. & Author(s) & Title & Area & Date \\
\hline 854 & $\begin{array}{l}\text { A. Ferrer-i-Carbonell } \\
\text { B. M. S. Van Praag }\end{array}$ & Income Satisfaction Inequality and Its Causes & 3 & $08 / 03$ \\
\hline 855 & $\begin{array}{l}\text { B. Irlenbusch } \\
\text { D. Sliwka }\end{array}$ & $\begin{array}{l}\text { Career Concerns in a Simple Experimental } \\
\text { Labour Market }\end{array}$ & 1 & $08 / 03$ \\
\hline 856 & D. Sliwka & $\begin{array}{l}\text { Management Incentives, Signaling Effects and } \\
\text { the Costs of Vertical Integration }\end{array}$ & 1 & $08 / 03$ \\
\hline 857 & $\begin{array}{l}\text { M. Francesconi } \\
\text { A. Muthoo }\end{array}$ & An Economic Model of Child Custody & 3 & $08 / 03$ \\
\hline 858 & C. U. Chiswick & $\begin{array}{l}\text { History of Historical Statistics of the United } \\
\text { States }\end{array}$ & 7 & $08 / 03$ \\
\hline 859 & R. Fahr & $\begin{array}{l}\text { Loafing or Learning? The Demand for Informal } \\
\text { Education }\end{array}$ & 5 & $08 / 03$ \\
\hline 860 & $\begin{array}{l}\text { J. Bonke } \\
\text { N. Datta Gupta } \\
\text { N. Smith }\end{array}$ & $\begin{array}{l}\text { Timing and Flexibility of Housework and Men } \\
\text { and Women's Wages }\end{array}$ & 5 & $08 / 03$ \\
\hline 861 & $\begin{array}{l}\text { Y. L'Horty } \\
\text { C. Rault }\end{array}$ & $\begin{array}{l}\text { Inflation, Minimum Wage and Other Wages: An } \\
\text { Econometric Study on French Macroeconomic } \\
\text { Data }\end{array}$ & 1 & $08 / 03$ \\
\hline 862 & $\begin{array}{l}\text { J. T. Addison } \\
\text { C. R. Belfield }\end{array}$ & Union Voice & 3 & $08 / 03$ \\
\hline 863 & C. U. Chiswick & $\begin{array}{l}\text { Immigrant Religious Adjustment: An Economic } \\
\text { Approach to Jewish Migrations }\end{array}$ & 1 & $08 / 03$ \\
\hline 864 & $\begin{array}{l}\text { D. Cobb-Clark } \\
\text { C. Ryan } \\
\text { R. Breunig }\end{array}$ & $\begin{array}{l}\text { A Couples-Based Approach to the Problem of } \\
\text { Workless Families }\end{array}$ & 6 & $08 / 03$ \\
\hline 865 & S. W. Polachek & $\begin{array}{l}\text { Mincer's Overtaking Point and the Lifecycle } \\
\text { Earnings Distribution }\end{array}$ & 5 & 08/03 \\
\hline 866 & A. Constant & $\begin{array}{l}\text { Immigrant Adjustment in France and Impacts on } \\
\text { the Natives }\end{array}$ & 1 & 08/03 \\
\hline 867 & $\begin{array}{l}\text { T. J. Dohmen } \\
\text { B. Kriechel } \\
\text { G. A. Pfann }\end{array}$ & $\begin{array}{l}\text { Monkey Bars and Ladders: The Importance of } \\
\text { Lateral and Vertical Job Mobility in Internal } \\
\text { Labor Market Careers }\end{array}$ & 1 & 08/03 \\
\hline 868 & $\begin{array}{l}\text { P. Brañas Garza } \\
\text { S. Neuman }\end{array}$ & $\begin{array}{l}\text { Analyzing Religiosity Within an Economic } \\
\text { Framework: The Case of Spanish Catholics }\end{array}$ & 5 & 08/03 \\
\hline
\end{tabular}

An updated list of IZA Discussion Papers is available on the center's homepage www.iza.org. 